out very many of theso suggestions and I cannot help wondering whether some of them are as useful as they appear. But it must be admitted that what may be successful with one class is not necessarily so with another; the user makes his own selection.

The experimental details are often good; for example, it is pointed out that the gas supply in somo districts may no longer contain the respiratory poisons so useful in anaesthetizing protozoa; yet the important warning for these times that glassware used for protozoa must not be washed in detergent is not there. The importance of identifying an animal and the use of comparative studies are both stressed, yet inexplicably all sea anemones are lumped together as if their behaviours would be the same. And in her desire to hang the experiments on a framework of theory, the author makes some remarkuble statoments; surely, for example, the molluses can hardly be called an "aberrant" group? It is pcrhaps misleading to suggest that the reaction of Hydra to glutathiono has something in common with the reactions of minnows to alarm substances. Although a chemical stimulus is involved in both, the bchaviour evoked is quite different and almost certainly the receptors involved bear little likeness to each other.

Nevertheless, this book contains many useful ideas which should stimulate teachers to try again with experi. mental work in behaviour. They will not lack direction for their theoretical reading, for Miss Hainsworth supplies a good list of selected references. The book is attractively produced and, apart from the transposition of two legends, the illustrations are clear and informative.

J. D. Carthy

\section{WATCHING BIG GAME}

A Field Guide to the National Parks of East Africa By John G. Williams. Pp. $352+32$ plates. (London: William Collins, Sons and Co., Ltd., 1967.) 45s. net. THis book has three sections which describe the wild life areas, their mammals and their rarer birds.

Sixty faunal areas covering about 50,000 square miles are discussed. Places of ornithological interest such as the Uganda forests are detailed, while some arcas like the 11,000 square mile Selous are treated briefly and yet others, Ankole, for example, although faunistically interesting, are scarcely mentioned. However, due emphasis is placed on such new and exciting parks as the Ruaha, Kidepo and Meru. Accompanying these descriptions are comprehonsive check lists of birds and mammals with maps and details of communications, which will be useful to tourists when planning their itineraries.

The mammal soction occupies a sixth of the book and is disappointingly brief about such conspicuous creatiures. The larger mammals and bats, of which tho author is particularly knowledgeable, are emphasized while Murids, with their attendant taxonomic problems, are dismissed as "seldom seen unless specially searched for. . . ."

Conciso descriptions of the mammals include details of their distribution and habitat, but I would also welcome descriptions of their seasonal movements and, for night identification, their calls. Some of the information in the literature on demography, nutrition and ethology would also be relevant. Such information when given is occasionally misleading; for example, we are told, without further qualification, that the "hippo" is $14 \mathrm{ft}$. long.

Why is far more space given to the rare Uganda cormorant than to elephants, despite the latter's inportance in many park ecosystems today? There is, for instance, no mention of their huge mobile ears as useful characteris tics for distiant identification or of the Congo race found in the Semliki Valley. The answer lies partly in John Williams's years of experience in the Coryndon Museum, Nairobi, and his intimate contact with the living material while on safari, from which he has acquired unparalleled knowledge of their taxonomy.

His taxonomic approach is essential in the section on rarer birds. It is hore that the Peterson method indicating diagnostic characters on the plates by pointers is most valuable. The plates drawn by Rena Fennessy, famous for current wildlife issues of East African postage stamps, although superb would benefit from a scale. This section supplements the author's previous field guido to the commoner birds, to which there are abundant crossreferences and without which visiting ornithologists will be lost.

This book will require regular revision to keep pace with scientific work, new areas and sightings such as greater kudu and oryx now confirmed from the Kidepo or to delete species like tho Queen Elizabeth Park hunting dog.

Our changing knowledge is emphasized by an example from the area with which I am most familiar: Ishasha lions do not climb trees so much to see over the grass, which is in any case short, but to avoid flies and heat.

This then is a guide for the taxonomically orientated tourist and the ornithological enthusiast. I hope that it will stimulate others, including East African schoolchildren and potential ecologists, to a greater awareness of these little known areas. Christopher R. FiELD

\section{OBITUARIES}

\section{Professor J. H. Taylor}

James Haward Taylor, AM, PhD, FGS, FRS, who held the chair of geology at King's College, University of London, was one of Great Britain's most distinguished goologists. His death by drowning while engaged on underwater research in the Seychelles is a sad loss to the science.

Educated at Clifton College and King's College, London, he obtained a Henry Fellowship to Harvard in 1933, returning to take up an appointment to HM Geological Survey. From this he was appointed professor of geology at his old college in 1949 .

His initial interest was in igneous rocks, which he studied in Leicestershire and the Isle of Man. His work at Harvard, on the Little Belt Mountains, Montana, led him to a study of mineralization, while his early work with the Geological Survey in the west Midlands stimulated his interest in the sedimentary formations. These interests coalesced when, during the Second World War, he was engaged on the study of the Northamptonshire iron-ore field. He made the petrology of these ores his special study, and his memoir on them has become a standard work on the subject. At the same time he maintained an active interest in their ficld occurrence, and with S. E. Hollingworth and G. A. Kellaway established the importance of periglacial superficial movements in their disposition. This in turn led to a study of the Pleistocene sequence and the goomorphology of the area.

A student mapping project in the central Weald revived his interest in these sediments, and his studies of this sequence are among his latest publications. He retained his interest in economic ores, however, extending his work to Broken Hill, Rhodesia. He was greatly interested, through earlier studies of Jurassic limestones in the English Midlands, in the genosis of these rocks, and in 1963 initiated a project to investigate recent limestone formation on the Seychelles Banks. Some of his students' work on this had been published, and the project contained the promise of exciting contributions in this new and expanding ficld. $\mathrm{He}$ travelled widely, in Europe, Africa and North America, and had a wide and varied knowledge of geology outside his special interests.

All Professor Taylor's work was marked by a moticulous 
attention to accuracy and to scientific discipline. He set himself the very highest standards of investigation and exposition. He applied the same conscientiousness to his numerous other duties; he served on the councils of the Geological Society, the Geologists' Association, the Mineralogical Society and the Institute of Mining and Metallurgy, being president of the last two; he was elected to a fellowship of the Royal Society in 1960, served on its council and became chairman of the British National Committee for Geology. He was a member of the Natural Environment Research Council and of the Iron and Steel Federation and the British Ceramic Research Association. During the past year he presided over the meetings of the International Sedimentological Congress at Reading and Edinburgh. All these, and his many other duties, he carried out with a zeal and an efficiency which were a constant source of amazement to all who knew him.

His public manner, apparently controlled and urbane, concealed a deeply shy and reserved nature. Despite this, however, all who were in contact with him immediately sensed a warmth of understanding. Unfailingly courteous, his time and energies were always at the service of his colleagues. He enjoyed the respect of all, and leaves a multitude of friends. J. E. Prentiof

\section{Dr P. J. du Toit}

DR P. J. DU ToIT, who died in Pretoria on November 13, 1967 , at the age of 79 , was one of South Africa's greatest men of science-first in the role of a brilliant young veterinary research worker, then as Dean of the Faculty of Veterinary Science at the Transvaal University College of South Africa, where he succeeded Sir Arnold Theiler in 1927, and later as Director of Veterinary Services in South Africa (1927-48), a responsibility which included guiding the destinies of the world-renowned Veterinary Research Institute at Onderstepoort.

While the careers of many lesser men may have ended there, at retirement, du Toit went on with characteristic enthusiasm and stamina to become the second President of the South African Council for Scientific and Industrial Research (CSIR) in 1951, succeeding Sir Basil Schonland. Later (1951-60) he was appointed President of the Scientific Council for Africa South of the Sahara (CSA)a non-governmental body that has since become a victim of political change in Africa. During these years, du Toit guided the activities of CSA at numerous meetings of the Commission for Technical Co-operation in Africa South of the Sahara (CCTA) held in East, Central, West and southern Africa.

Du Toit's academic qualifications included a BA (Hons.); PhD (with honours) from Zurich University; and a doctorate in veterinary science, with honours, from Berlin. He held six honorary doctorates at the time of his death, four from South African universities which recognized his outstanding contribution to science in Africa, and one each from the universities of Utrecht, Holland and Glasgow.

Du Toit was a Fellow of the Roval Society and belonged to twelve scientific societies all over the world. He served on many commissions, enquiring into education, veterinary science, agricultural science, medicine, museums and so on, and represented South Africa at many international conferences. He wrote more than 140 publications.

His early interest during the First World War, when he was allowed to continue his research in Germany despite the fact that he held a British passport, was leukaemia in cattle. He received a doctorate in veterinary science for this work from the University of Berlin and later collaborated with Professor P. Knuth on tropical veterinary problems. He was co-author with Knuth of a standard textbook (in German) on tropical diseases in domestic animals.

Du Toit returned to South Africa in 1919 to carry on with the fundamental research into lamsiekte (bovine botulism) begun by Sir Arnold Theiler. This was to have far-reaching results in the development of the study of mineral deficiencies. By 1928 he had focused his attention on protozoology and virus diseases as professor at the Transvaal University College of South Africa. A year before, he had visited Nigeria and reported on veterinary matters there at the request of the Colonial Office in the United Kingdom.

Despite growing administrative burdens, du Toit's research continued in earnest until after he retired as Director of Veterinary Services of the South African Department of Agriculture, and Dean of the Faculty of Veterinary Science, University of Pretoria, in 1948. A cross-section of his publications reveals interests ranging from rinderpest to iodine in the nutrition of sheep; from problems of immunity in animal diseases to studies of the mineral content and feeding value of natural pastures in South Africa.

It is difficult to write an appreciation of a scientist such as P.J. du Toit, for he would have been the first to contend that the praise was undeserved and his achievements were mainly due to the efforts of his colleagues. He will be remembered as an outstanding administrator with a mind comprehensive in its grasp of things and simple and precise in its setting out of a problem. In addition to his scientific and academic responsibilities he gave much time to public work of various kinds, including active membership of the South African Historical Monuments Commission.

As a personality, he will be remembered for his keen sense of humour and charming companionship. He was in great demand as a raconteur and after-dinner speaker, accomplishments which earned him the affectionate sobriquet "P. J.". He never flaunted his own achievements nor underrated the work of others. S. M. NAUDÉ

\section{Professor G. Z. Dimitroff}

Georae Z. Dimitroff, emeritus professor of astronomy at Dartmouth College, Hanover, New Hampshire, and former superintendent of the Harvard Observatory, died on January 1 at his home in Hartland, Vermont, at the age of 66. He had been a member of Dartmouth's astronomy department for twenty years before his retirement in June 1966.

A native of Svistove, Bulgaria, Dimitroff graduated from the University of Boston in 1927 and took his MA and $\mathrm{PhD}$ degrees at Harvard. He taught physics at Colorado State College and astronomy at Harvard and Radcliffe.

For five years before he went to Dartmouth, Dimitroff was superintendent of the Harvard Observatory where he helped to build some of the largest Schmidt cameras in existence before that at Mount Palomar was built. He advised the Mexican government about the building of their astrophysical observatory at Puebla, and was coauthor of a book on telescopes and accessories.

For hundreds of Dartmouth undergraduates Astronomy 1 and Professor Dimitroff were synonymous. In addition to this introductory course in stellar astronomy and the astronomical universe, popularly known as "stars", he also taught more advanced courses in astrophysics and observational astronomy. His open house "Evening with the Stars" at the Shattuck Observatory gave pleasure to many Hanoverians, young and old.

As a commander in the US Navy in the Second World War, Dimitroff undertook a variety of scientific missions in Europe and Japan, including studies of optical developments there. On leave from Dartmouth in 1956, he surveyed astronomical developments in Europe and the Middle East, and at that time was scientific liaison officer with the US embassy in London. He went to Russia in 1958 as a member of the International Astronomical Union and returned there in 1963 as part of a world tour of observatories. Impressed with Russian scientific advances, he predicted that in twenty years Russia would be the leading scientific nation. 